\title{
Model Latent Dirichlet Allocation Pada Perilaku Siswa Menggunakan Media Pembelajaran Daring
}

\author{
Aqila Intan Prakerti ${ }^{1}$, Avelyna Ferariya Claresta ${ }^{1}$, Muhammad Rasyid Kafif Ibrahim ${ }^{1, *}$, Nur \\ Aini Rakhmawati ${ }^{1}$
}

\begin{abstract}
${ }^{1}$ Sistem Informasi; Institut Teknologi Sepuluh Nopember; Jl. Teknik Kimia, Keputih, Kec. Sukolilo, Kota SBY, Jawa Timur 60111, 031 5994251; e-mail: aqilaintan@gmail.com, avelyna02@gmail.com, m.rasyidkafif@gmail.com, nur.aini@its.ac.id
\end{abstract}

* Korespondensi: e-mail: m.rasyidkafif@gmail.com

Diterima: 07 November 2020 ; Review: 29 November 2020; Disetujui: 10 Desember 2020

Cara sitasi: Prakerti Al, Claresta AF, Ibrahim MRK, Rakhmawati NA. 2020. Model Latent Dirichlet Allocation Pada Perilaku Siswa Menggunakan Media Pembelajaran Daring. Information Management for Educators and Professionals. 5 (1): 35-44.

\begin{abstract}
Abstrak: Indonesia saat ini sedang dihebohkan dengan yang namanya sekolah Daring. Dimana yang seharusnya sekolah adalah tempat untuk guru dan siswa mengajarkan ilmu dari pendidikan hingga perilaku secara tatap muka dan sekarang karena keadaan yang tidak bisa dihindari maka harus dilakukannya pembelajaran secara online yaitu dengan alat perantara. Permasalahan diambil dari banyaknya siswa sudah mempunyai alat komunikasi yaitu handphone dan berbagai media sosial yang sudah dikuasai seperti Instagram. Dengan maksud untuk menganalisa siswa khususnya di Indonesia, sikap apa yang diambil ketika siswa menggunakan Instagram ketika sedang berlangsungnya pembelajaran secara daring. Didapatkan hasil ketika melakukan Teknik crawling data untuk mendapatkan teks atau caption dari penggunaan hashtag sekolah daring yaitu 120 post dalam keadaan sudah terseleksi dari yang bukan post dari siswa. Bentuk analisa untuk pengolahan data yang sudah didapat menggunakan model Latent Dirichlet Allocation (LDA) yaitu untuk menemukan topik yang mendominasi dari hashtag yang digunakan dengan penambahan fitur Stopword untuk kata yang tidak diperlukan. Hasil akhir dari analisa tersebut terdapat 4 topik yang dominan dan dimayoritasi oleh siswa yang mendapatkan penugasan dari sekolah seperti pelajaran biologi.
\end{abstract}

Kata kunci: Instagram, Latent Dirichlet Allocation (LDA), Pembelajaran Daring,

\begin{abstract}
Indonesia is currently being shocked by the named school Online. Where the school should be a place for teachers and students to teach knowledge from education to face-to-face behavior and now because of circumstances that cannot be avoided,learning must be carried out online, namely with an intermediary tool. The problem is taken from the number of students who already have communication tools, namely mobile phones and various social media that have been mastered such as Instagram. With a view to analyzing students, especially in Indonesia, what attitudes are taken when students use Instagram when learning is taking place online. Obtained results when performing techniques crawling data to get text or captions from the use hashtags, of online school namely 120 posts in a selected state from non-posts student. The form of analysis for processing the data that has been obtained uses the model, Latent Dirichlet Allocation (LDA) which is to find the dominant topic of the hashtags used by adding the feature Stopword for unnecessary words. The final result of the analysis, there are 4 topics that are dominant and are majored by students who get assignments from schools such as biology lessons.
\end{abstract}

Keywords: E-Learning, Instagram, Latent Dirichlet Allocation (LDA). 


\section{Pendahuluan}

Beberapa pemerintah daerah memutuskan menerapkan kebijakan untuk meliburkan siswa dan mulai menerapkan metode belajar dengan sistem daring (dalam jaringan) atau online. Pada tanggal 24 maret 2020 Menteri Pendidikan dan Kebudayaan Republik Indonesia mengeluarkan Surat Edaran Nomor 4 Tahun 2020 Tentang Pelaksanaan Kebijakan Pendidikan Dalam Masa Darurat Penyebaran COVID, dalam Surat Edaran tersebut dijelaskan bahwa proses belajar dilaksanakan di rumah melalui pembelajaran daring/jarak jauh dilaksanakan untuk memberikan pengalaman belajar yang bermakna bagi siswa[1]. Pembelajaran daring adalah bentuk pembelajaran yang mampu menjadikan siswa mandiri tidak bergantung pada orang lain. Hal ini dikarenakan melalui pembelajaran daring siswa akan fokus pada layar gawai untuk menyelesaikan tugas ataupun mengikuti diskusi yang sedang berlangsung[2]. Khususnya pembelajaran secara umum dan sekarang dilakukan dengan daring rasanya seperti terdapat transisi atau perubahan sistem dimana biasanya memerlukan adapatasi dan proses yang pastinya diluar dari ekspektasi karena situasi seperti ini pun tidak direncanakan dan termasuk mendadak.

Perilaku adalah respons individu atau suatu tindakan yang dapat diamati dan mempunyai frekuensi spesifik, durasi dan tujuan baik disadari maupun tidak. Perilaku merupakan kumpulan berbagai factor yang saling berinteraksi. Dalam UU No. 2/1989, bahwa pendidikan adalah usaha sadar untuk menyiapkan peserta didik melalui kegiatan bimbingan, pengajaran dan latihan bagi peranannya di masa yang akan datang.[3]

Sekolah merupakan media pembelajaran untuk membentuk sebuah karakter masingmasing siswa baik dari sopan santun, moral etika, bahkan sikap. Pembangunan karakter dan pendidikan karakter menjadi suatu keharusan karena pendidikan tidak hanya menjadikan peserta didik cerdas, juga mempunyai budi pekerti dan sopan santun sehingga keberadaannya sebagai anggota masyarakat menjadi bermakna baik bagi dirinya maupun orang lain[4]. Ketika seorang guru mengajarkan ilmu baru kedalam siswa sebenarnya akan lebih efektif jika memang sesuatu tersebut berbentuk nyata. Contoh dari guru mengajarkan sesuatu yang istilahnya bekal untuk siswa menuju kehidupan selanjutnya yaitu ketika berlangsungnya pembelajaran efektif, guru melarang siswa untuk mengakses telepon genggam ketika sedang tidak diperlukan untuk pembelajaran. Hal seperti itu pasti mempunyai maksud yaitu guru ingin siswanya patuh terhadap peraturan dan menjadikan siswa saling menghargai satu sama lain. Ketika dilakukan dan diterapkan secara langsung tanpa perantara, maksud dari peraturan yang ada di sekolah sangatlah berguna dan guru bisa mengontrol siswanya secara mudah.

Ketika dunia semakin menuju era yang lebih maju yaitu modern dan teknologi, permalasahan baru secara tidak langsung muncul. Salah satu permasalahan tersebut ada di teknologi, dimana teknologi ini termasuk internet, jaringan, dan perantara virtual lainnya. Teknologi sangat diminati, mengapa demikian? karena teknologi bisa mendekatkan sesuatu yang jauh secara cepat dan sederhana bisa terasa dekat. Setelah adanya teknologi ini muncullah platform atau media yang menyediakan wadah untuk teknologi tersebut kebagianbagian bidang tertentu. Contoh untuk platform komunikasi, berbagi informasi dan membuat karya bisa menggunakan Instagram, WhatsApp, dan lain sebagainya. Dimana media platform tersebut sangat menjadi kebutuhan masyarakat pada era ini dan berujung ketergantungan dari platform tersebut. Yang dulu masyarakat minim mempunyai alat teknologi dan sekarang hampir semua orang membutuhkan alat tersebut, karakter masyarakatpun bisa dipengaruhi dari perubahan era ini. Dengan menggunakan teknologi tersebut, pembelajaran daring memudahkan guru untuk memberikan materi dan diskusi setiap saat melalui jaringan internet. Disisi lain, memudahkan siswa untuk mengunduh materi maupun melakukan diskusi yang berkaitan dengan mata pelajaran yang ada[5].

Menteri Pendidikan dan Kebudayaan menyebutkan pembelajaran daring sebagai proses beradaptasi dengan teknologi. Adaptasi dengan teknologi bagi anak-anak adalah hal yang jauh lebih mudah. Apalagi, saat ini sekolah berhadapan dengan generasi Z. Generasi yang sangat lekat dan akrab dengan gawai atau teknologi digital. Karena itu sebenarnya anak-anak lebih mudah beradaptasi untuk menggunakan teknologi. Adaptasi teknologilah yang kemudian mendorong anak-anak untuk mudah bermigrasi ke era industri 4.0. Selama ini mungkin anakanak belum sepenuhnya menyadari bahwa era industri 4.0 membuat efisiensi waktu dan tenaga kerja. Dengan adanya Undang-Undang No. 14 Tahun 2005 tentang Guru dan Dosen, seorang guru profesional dituntut bukan hanya menguasai tentang pencarian informasi digital, tetapi juga harus menguasai tentang pembuktian keabsahan informasi tersebut[6]. 
Permasalahan untuk saat ini dalam bidang Pendidikan bagi siswa yaitu ketika ada imbauan surat edaran dari pemerintah yang ada yaitu Nomor 36962/MPK.A/HK/2020 tentang Pembelajaran secara Daring dan Bekerja dari Rumah dalam Rangka Pencegahan Penyebaran Covid-19 apakah seorang guru atau pihak sekolah mampu membentuk karakter siswa dalam pantauan jarak jauh dan dengan menggunakan perantara. Maka dari itu penulis ingin melakukan survey lebih rinci untuk permalasahan ini didalam karya tulis ini.

Tujuan dari Karya Tulis IImiah ini bertujuan untuk menganalisa perilaku siswa dalam dunia maya saat sekolah Daring. Lebih spesifiknya penelitian untuk analisa ini membahas bentuk dunia maya yaitu media sosial berbentuk aplikasi yang hampir semua masyarakat memiliki akses atau bisa menggunakan aplikasi tersebut yang bernama Instagram. Diambil dari permasalahan ketika penggunaan sosial media itu dalam pembelajaran Daring berlangsung, harapan yang diinginkan untuk hasil analisanya adalah siswa tetap memperlakukan sekolah Daring layaknya sekolah seperti tatap muka secara langsung yaitu minimnya penggunaan gadget untuk mengakses media sosial saat pembelajaran berlangsung.

\section{Metode Penelitian}

Untuk mempermudah proses analisa siswa dalam pembelajaran daring pada masa kini maka penulis perlu mengumpulkan data-data yang terkait dalam proses penelitian.

\section{Data Primer}

Untuk data primer yang digunakan yaitu dengan cara observasi dengan siswa-siswa yang terpilih dengan pengamatan secara real-time selama satu minggu. Kategori siswa yang terpilih ini adalah siswa yang selama pembelajaran daring berlangsung aktif melakukan kegiatan dalam media sosial khususnya di Instagram. Selebihnya untuk informasi lebih dalam penulis juga melakukan wawancara terhadap siswa mengenai durasi atau waktu siswa memulai pembelajaran daring hingga selesai di sekolah asalnya. Lalu untuk melihat perilaku siswa di Instagram secara menyeluruh, penulis menggunakan Teknik crawling data. Teknik crawling data merupakan kegiatan berpindah-pindah di antara halaman web secara otomatis selama web scrapping bekerja. Crawling adalah aktifitas dalam membuat Salinan dalam porsi yang relevan yang diambil dari sebuah World Wide Web[7]. Teknik crawling data juga merupakaan Teknik pengumpulan data dengan filter yang digunakan. Filter tersebut merupakan sebuah hashtag dan dari hashtag tersebut menghasilkan isi atau caption yang ada. Dan hasil dari Teknik tersebut kita seleksi lagi untuk mencari suatu caption yang digunakan oleh siswa bukan berita maupun spam.

Pengguna sosial media di Indonesia mencapai 79 juta di tahun 2016 dimana setara dengan 30 persen total populasi penduduk. Lebih detil, penggunaan sosial media dengan jenis mobile phone tercatat sebanyak 66 juta, dimana telah mewakili 25 persen dari total penduduk di Indonesia. Dari semua jenis sosial media yang ada, penggunaan Instagram telah digunakan oleh jutaan user yang aktif menggunakan sosial media. Pada pertengahan tahun 2016, Instagram telah tercatat memiliki 500 juta pengguna di seluruh dunia, dimana pertumbuhan meningkat dua kali lipat dalam kurun waktu dua tahun. Lebih lanjut, sebanyak 300 juta akun yang ada merupakan pengguna Instagram harian[8].

Pada penelitian ini digunakan salah satu social media yaitu Instagram. Instagram merupakan sebuah aplikasi khusus berbagi foto dengan fungsinya untuk mengunggah foto (upload), mengambil foto (download), mengedit foto, menambahkan filter digital foto (efek foto), memberi komentar pada foto, memberi judul foto, memberi lokasi foto, memberi tanda like pada foto, dan 35 membagikan foto ke berbagai layanan jejaring sosial lainnya. Media sosial yang paling sering digunakan saat ini adalah instagram. Instagram merupakan salah satu jejaring sosial photo and video sharing yang sukses diminati oleh masyarakat di seluruh dunia, terutama bagi remaja. Indonesia menjadi negara dengan pengguna instagram terbesar se-Asia Pasifik. Dari 700 pengguna aktif bulanan atau monthly active user yang diraup instagram secara global, 45 juta di antaranya berasal dari Indonesia[9]. Indonesia merupakan negara dengan pengguna aktif di Instagram terbanyak ketiga di dunia dengan jumlah pengguna aktif sebanyak 53 juta pengguna[10].

\section{Data Sekunder}

Data sekunder digunakan untuk melengkapi serta mendalami poin-poin penting dalam proses analisa ini. Data sekunder yang meliputi studi literatur dari karya tulis ilmiah berbentuk 
jurnal, tesis, atau karya tulis ilmiah dalam bentuk lain yang telah dibuat oleh orang lain digunakan sebagai pedoman penulis untuk melancarkan analisa ini.

\section{Tahapan Penelitian}

Tahapan penelitian ini merupakan suatu proses untuk menghasilkan nilai didalam karya tulis ini. Tahapan yang digunakan sesuai dengan tema dan judul yang dibahas dari teori, konsep, studi literatur, observasi, hingga implementasi sampai hasil dan pembahasan. Tahapan penelitian meliputi:

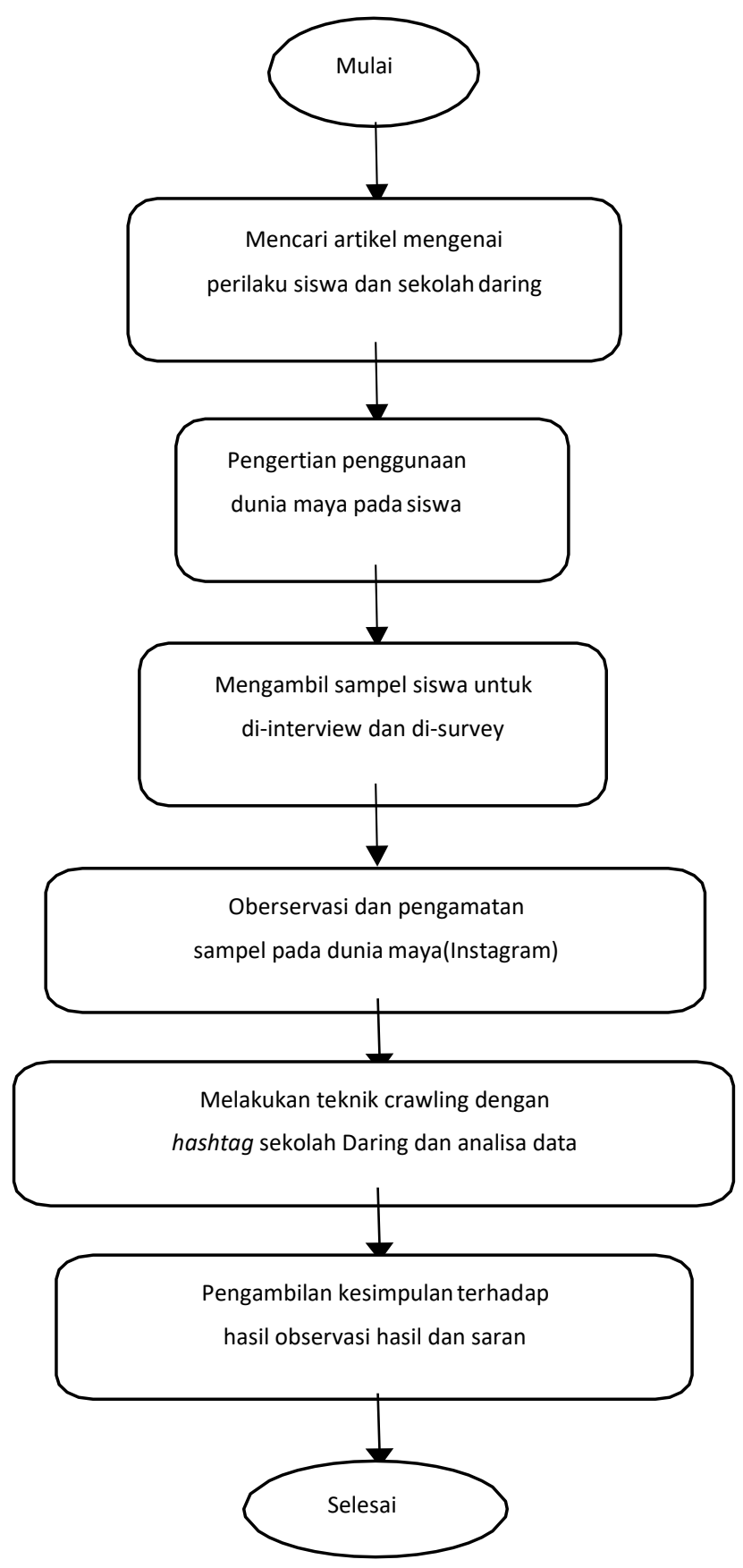

Sumber: Hasil Penelitian (2020)

Gambar 1. Tahap Metode Penelitian 
Gambar di atas menjelaskan tentang alur proses awal melakukan penelitian dari mencari artikel mengenai perilaku siswa dan sekolah daring, dilanjutkan dengan mengambil sampel siswa untuk di-interview dab di-survey hingga pengambilan kesimpulan terhadap hasil observasi dan saran.

Analisa data yang sudah didapatkan dari Teknik Crawling Data pada penelitian ini menggunakan Latent Dirichlet Allocation (LDA). Latent Dirichlet Allocation (LDA) merupakan salah satu metode yang menggunakan teori statistik yang sudah banyak digunakan secara luas baik dalam hal pembelajaran mesin, pengolahan data, maupun pengolahan citra. Metode ini pertama kali dibuat dan dipublikasikan oleh Ronald A. Fisher melalui paper The Use of Multiple Measure in Taxonomic Problems pada tahun 1936. LDA adalah metode ekstraksi fitur dengan perpaduan dari perhitungan operasi matematika dan statistika yang menggunakan properti statistik terpisah untuk tiap obyek[11].

LDA bekerja berdasarkan analisis matriks penyebaran yang bertujuan menemukan suatu proyeksi optimal sehingga dapat memproyeksikan data input pada ruang dengan dimensi yang lebih kecil dimana semua pola dapat dipisahkan semaksimal mungkin. Karenanya untuk tujuan pemisahan tersebut maka LDA akan mencoba untuk memaksimalkan penyebaran data-data input di antara kelas-kelas yang berbeda dan sekaligus juga meminimalkan penyebaran input pada kelas yang sama. Perbedaan antar kelas direpresentasikan oleh matriks $\mathrm{Sb}$ dan perbedaan dalam kelas direpresentasikan oleh matriks Sw. Berikut langkah-langkah pembentukan vektor fitur citra wajah menggunakan metode LDA[12].

\section{Hasil dan Pembahasan}

Hasil dan pembahasan pada penelitian ini mencakup hasil observasi dan survey sampel, teknik crawiling data, dan proses analisa dengan LDA.

\section{Hasil Observasi dan Survey Sampel}

Hasil dari pengamatan dengan sampel siswa yang terpilih secara survey, yaitu siswa yang selama pembelajaran daring berlangsung aktif melakukan kegiatan dalam media sosial khususnya di Instagram. Penulis mengambil beberapa siswa yang telah diamati selama satu minggu yaitu pada tanggal 2 September 2020 hingga 9 September 2020 berlokasi di Gresik, Jawa Timur yang mempunyai akun instagram bernama: 1) @aurelsilalahi (SMA Semen Gresik), 2) @salsauzt (SMA Negeri 1 Manyar) dan 3) @yogirlzae (SMA Semen Gresik).

Dengan hasil pengamatan selama satu minggu penulis juga melakukan survey mengenai jam efektif sekolah pada masing-masing sekolah. Dan hasil survey yang didapatkan: 1) SMA Semen Gresik waktu efektif sekolah mulai hari Senin-Jumat pukul 07.00 hingga 15.20 via zoom. 2) SMA Negeri 1 Manyar waktu efektif sekolah mulai hari Senin-Jumat pukul 07.00 hingga 11.30 via zoom.

\section{Teknik Crawling Data}

Untuk pengamatan siswa menyikapi media sosial yaitu Instagram ketika jam sekolah berlangsung, penulis tidak mendapatkan suatu hasil yang dilakukan oleh siswa tersebut. Langkah selanjutnya adalah melakukan penulurusan siswa secara keseluruhan dengan melakukan Teknik crawling data dengan hashtag. Hashtag yang digunakan untuk penelurusan karya tulis ini adalah \#sekolahdaring. Untuk mendapatkan data berupa teks yang murni dari perilaku yang dilakukan oleh siswa, diadakan seleksi secara manual seperti penghilangan teks berupa berita, spamming, serta akun orang tua dari siswa.

Caption dari hashtag yang digunakan sebagian kecil sebagai berikut;

Tabel 1. Hasil Teknik Crawling Data

\begin{tabular}{lll}
\hline No. & Username & Caption \\
\hline 1 & 0.azah10 & Metabolisme \\
& & Nama: Octafian Az-zahra \\
& Kelas: XII IPA 2 \\
& No. Absen: 25 \\
& & \#tugasclassroombiologi \#dirumahaja \#sekolahdaring @primaimaa \\
\hline 2 & dinda.a.putri.568 29446 & Pikiran yang tenang membawa kekuatan batin dan percaya diri sehingga \\
& & itu sangar penting untuk kesehatan yang baik. Saya Dinda adiya putri \\
& kelas 7B. Siap menjadi generasi yg cinta olahraga. \\
&.. \\
& \\
& &.. \\
& \\
&
\end{tabular}




\begin{tabular}{|c|c|c|}
\hline No. & Username & Caption \\
\hline & & $\begin{array}{l}\text { SMP KREATIF AN-NUR SURABAYA!!!! } \\
\text { INDONESIA!!!! JAYA LUAR BIASA!!!! }\end{array}$ \\
\hline & & .. \\
\hline & & .. \\
\hline & & \#smpkreatifannur \#ssmpkreatifannursurabaya \#ssmpkreatifannursby \\
\hline & & \#smpsurabya \#smphits \#sekolahkreatif \#sekolah impian \#sekolahpilihan \\
\hline & & \#sekolah islam \#kemendikbud \#kemendikbud_ri \#dispendiksby \\
\hline & & \#aslisurabaya \#tugas sekolah \#tugasonline \#sekolahdaring \\
\hline & & \#sekolahonline \#daringonline \#goesnewnormal \#ayosekolah \\
\hline & & $\begin{array}{l}\text { \#indonesiasehat \#surabayasehat \#pendidikanolahraga \#pjok \#sporty } \\
\text { \#ilovesporty }\end{array}$ \\
\hline & & .. \\
\hline & & .. \\
\hline & & @smpkreatifannursurabaya dan @gandangekap \\
\hline 3 & tya.na & Tugas sekolah \\
\hline & & $\begin{array}{l}\text { Mengenal dan bermain peran dg benda dapur Mengenal dan menarik } \\
\text { huruf vocal yang sama } 08 \text { September } 2020\end{array}$ \\
\hline & & . \\
\hline & & \#sekolahdaring \#belajardirumah \\
\hline 4 & dyawdyaa & " Tugas Wayang Purwa Bag 1 " \\
\hline & & NAMA : ALYA WIDYA M \\
\hline & & NOMOR : 04 \\
\hline & & KELAS : X MIPA 1 \\
\hline & & @_satriobagus \\
\hline & & \#bahasajawa \\
\hline & & \#wayangpurwa \\
\hline & & \#bosojowo \\
\hline & & \#likeforlikes \\
\hline & & \#janganlupalike \\
\hline & & \#likelike \\
\hline & & \#instagram \\
\hline & & \#sekolahdaring \\
\hline & & \#samasamabelajar \\
\hline & & \#semangatdaring \\
\hline 5 & kailash_kboy & Tugas Kailash hari Senin tanggal 24 Agustus 2020: \\
\hline & & 1. Mewarnau huruf $d$ dengan warna biru \\
\hline & & 2. Hafalan Asmaul Husna (Ya Aziz - Ya Khahar) \\
\hline & & 3. Hafalan doa naik kendaraan \\
\hline & & . \\
\hline & & \#sekolahonline \#sekolahdarirumah \#sekolahdaring \\
\hline & & \#onlineclass \#tkkhalifah7 \#sekolahpalembang \\
\hline 6 & fadhillaharyskha12 & Nama: Aryskha Noer Fadhillah \\
\hline & & Kelas: XII IPA 7 \\
\hline & & Guru biologi: bu @primaimaa \\
\hline & & \#sekolahdaring \\
\hline & & \#belajardirumah \\
\hline & & \#tugaspraktikumbiologi \\
\hline 7 & ndysyp19 & Tugas Pkn \\
\hline & & @enirohaeni85 \\
\hline & & @smkpersadakotasukabumi \\
\hline & & \#kemerdekaan indonesia \\
\hline & & \#nkri \\
\hline & & \#sekolahdaring \\
\hline & & \#tugasdaring \\
\hline & & \#17agustus \\
\hline & & \#newnormal \\
\hline & & \#belajardirumah \\
\hline & & \#persada \\
\hline & & \#semangatbelajar \\
\hline
\end{tabular}

Sumber: Hasil Penelitian (2020)

Pada tabel 1 ditampilkan beberapa hasil dari data yang didapatkan dari Teknik Crawling Data. Username sampel yang diambil pada tabel ini bernama o.azah10, dinda.a.putri.568 29446, tya.na, dyawdyaa_, kailash_kboy, fadhillaharyskha12, ndysyp19. 


\section{Proses Analisa Data dengan LDA}

Berdasarkan data yang didapat dari Teknik tersebut kami menemukan data siswa yang menyikapi media sosial Instagram ini dikarenakan adanya tugas dari sekolah dan data yang sudah di seleksi untuk karya tulis ini sebanyak 120 caption. Untuk meng-highlight dari banyaknya caption yang ada menjadi kelompok-kelompok topik yang berkaitan dengan sekolah daring, penulis melakukan analisa data dari proses penggunaan LDA(Latent Dirichlet Allocation). Hasil dari proses pengolahan data untuk dianalisis tersebut menghasilkan data berbentuk diagram batang, seperti;

Jumlah Post Berdasarkan Topik

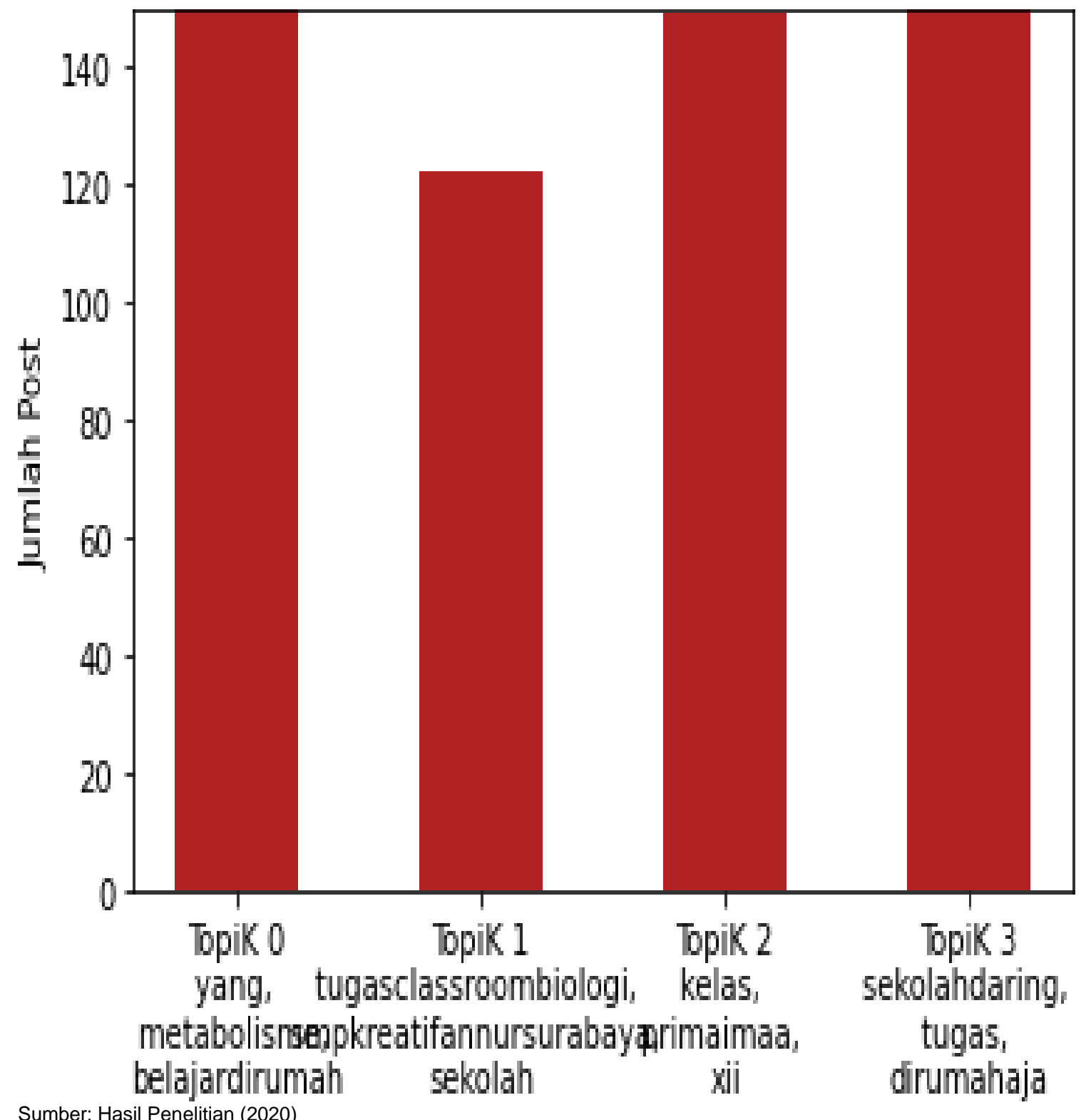

Gambar 2. Hasil Analisa Data dengan LDA

Sekilas dari data yang terpampang, bisa disimpulkan bahwa kegiatan siswa ketika mempergunakan media sosial khususnya Instagram pada waktu sekolah telah masuk adalah untuk keperluan sekolah yaitu penugasan dan sebagian besar merupakan tugas pelajaran biologi. Dan untuk hasil jumlah post yang terdapat pada tiap-tiap topik adalah: 1). Topik $0: 397$ Post dengan kata yang menjadi highlight yang, metabolism, belajardirumah, 2). Topik 1: 122 Post dengan kata yang menjadi highlight tugasclassroombiologi, smpkreatifannursurabaya, 3). 
Topik 2 : 149 Post dengan kata yang menjadi highlight kelas, primaiima, xii, 4). Topik $3: 261$ Post dengan kata yang menjadi highlight sekolahdaring, tugas, dirumahaja.

Untuk lebih menelusuri topik yang lebih rinci, penulis melakukan pembersihan data dengan menghilangkan kata(Stopword) yang sekiranya tidak perlu digunakan untuk analisa karya tulis ilmiah ini seperti: nama siswa, kelas, yang, nama sekolah, dan lain sebagainya. Bentuk grafik setelah menggunakan Stopword adalah sebagai berikut;

Jumlah Post Berdasarkan Topik

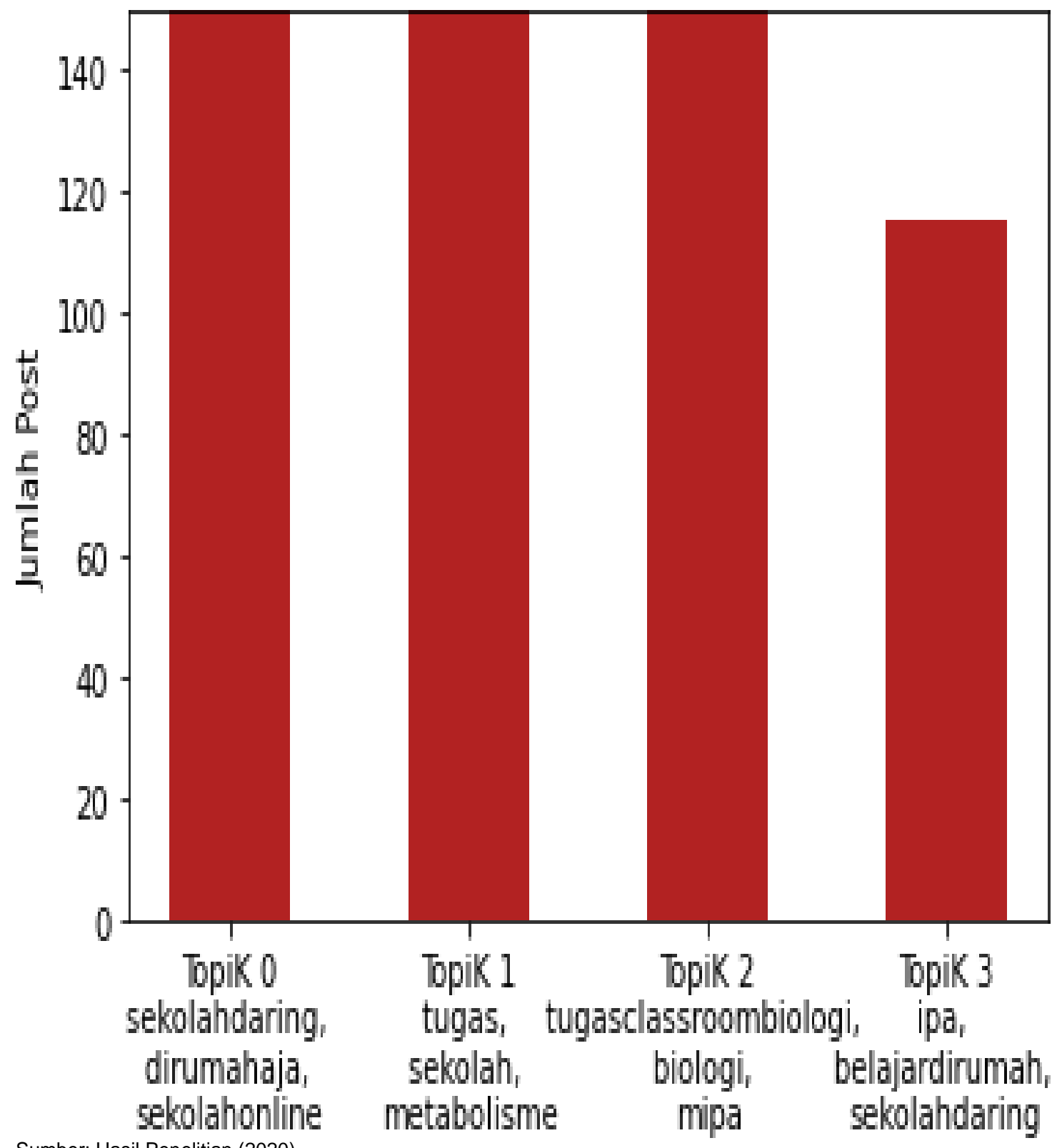

Sumber: Hasil Penelitian (2020)

Gambar 3. Hasil Analisa Data menggunakan Stopword

Menunjukkan bahwa grafik yang menggunakan peringatan kata yang tidak diperlukan(Stopword) untuk memperoleh data dari hashtag sekolah daring yang lebih spesifik ditunjukan dalam grafik 2 diatas. Untuk banyaknya post ditiap-tiap topik dijabarkan seperti berikut; 1). Topik $0: 508$ Post dengan kata yang menjadi highlight sekolahdaring, dirumahaja, sekolahonline, 2). Topik 1: 156 Post dengan kata yang menjadi highlight tugas, sekolah, metabolism, 3). Topik 2 : 150 Post dengan kata yang menjadi highlight tugasclassroombiologi, 
biologi, mipa, 4). Topik 3 : 115 Post dengan kata yang menjadi highlight ipa, belajardirumah, sekolah daring

\section{Kesimpulan}

Berdasarkan hasil serta pembahasannya yang telah dibahas pada bagian sebelumnya, maka dapat ditarik kesimpulan bahwa Instagram merupakan platform media sosial yang bisa juga digunakan untuk kepentingan sekolah dalam hal penugasan. Mengapa demikian? Ketika penulis melakukan Teknik crawling data untuk mendapatkan teks dari hashtag yang diminta yaitu sekolah daring, data yang terkumpul mencapai kurang lebih 2500 jumlah post termasuk post berisi berita dan spamming. Untuk karya tulis ilmiah ini penulis hanya memakai data hasil crawling hanya 120 teks/caption dan sudah tidak termasuk teks berupa berita dan spamming, murni dari postingan pemilik akun yang masih menginjak Pendidikan sekolah dasar, menengah pertama hingga menengah keatas. Kemudian dari data yang sudah di filter akan digunakan pengolahan data menjadi data statistic menggunakan model LDA.

Hasil dari pengolahan data statistik tersebut membuktikan bahwa dari pembawaan hashtag sekolah daring sendiri mayoritas topik yang dibawa dari post yang dilakukan siswa adalah 397 post untuk yang, metabolisme, belajardirumah, kemudian 122 post untuk tugasclassroombiologi, smpkreatifannursurabaya, sekolah, serta 149 post untuk kelas, primaimaa, xii, dan yang terakhir 261 post untuk sekolahdaring, tugas, dirumahaja. Dari data tersebut ternyata topiknya masih terdapat beberapa yang tidak berkaitan seperti kata "yang", maka pada kelangsungan model LDA ini penulis akhirnya menggunakan fitur tambahan yaitu Stopword yang merupakan pembersihan kata yang tidak berkaitan. Hasil data statistik ketika menggunakan Stopword adalah 508 Post sekolah daring, dirumahaja, sekolahonline, 156 Post tugas, sekolah, metabolism, 150 Post tugasclassroombiologi, biologi, mipa, dan 115 Post untuk ipa, belajardirumah, sekolahdaring

\section{Referensi}

[1] W. A. F. Dewi, "Dampak Covid-19 Terhadap Implementasi Pembelajaran Daring Di Sekolah Dasar," Edukatif J. Ilmu Pendidik., Vol. 2, No. 1, Pp. 55-61, Apr. 2020, Doi: 10.31004/Edukatif.V2i1.89.

[2] A. S. Syarifudin, "Impelementasi Pembelajaran Daring Untuk Meningkatkan Mutu Pendidikan Sebagai Dampak Diterapkannya Social Distancing," J. Pendidik. Bhs. Dan Sastra Indones. Met., Vol. 5, No. 1, Pp. 31-34, Apr. 2020, Doi: 10.21107/Metalingua.V5i1.7072.

[3] B. Edwandar, “Jom Fisip Vol. 4no. 1 - Februari 2017 Page 1," Vol. 4, No. 1, Pp. 1-15, 2017.

[4] E. Rohendi, "Pendidikan Karakter Di Sekolah," Eduhumaniora / J. Pendidik. Dasar Kampus Cibiru, 2016, Doi: 10.17509/Eh.V3i1.2795.

[5] M. Dimyati A, D. Suwardiyanto, H. Yuliandoko, And V. Arief W, "Pemanfaatan Teknologi Sebagai Media Pembelajaran Daring (On Line) Bagi Guru Dan Siswa Di Smk Nu Rogojampi," J-Dinamika, Vol. 2, No. 2, Feb. 2018, Doi: 10.25047/J-Dinamika.V2i2.565.

[6] A. Roni Hamdani And A. Priatna, "Efektifitas Implementasi Pembelajaran Daring (Full Online) Dimasa Pandemi Covid- 19 Pada Jenjang Sekolah Dasar Di Kabupaten Subang," Didakt. J. Ilm. Pgsd Stkip Subang, Vol. 6, No. 1, Pp. 1-9, 2020, Doi: 10.36989/Didaktik.V6i1.120.

[7] I. N. Husada, E. H. Fernando, H. Sagala, A. E. Budiman, And H. Toba, "Ekstraksi Dan Analisis Produk Di Marketplace Secara Otomatis Dengan Memanfaatkan Teknologi Web Crawling," J. Tek. Inform. Dan Sist. Inf., 2020, Doi: 10.28932/Jutisi.V5i3.1977.

[8] A. Santoso, I. Baihaqi, And S. F. Persada, "Pengaruh Konten Post Instagram Terhadap Online Engagement: Studi Kasus Pada Lima Merek Pakaian Wanita," J. Sains Dan Seni Its, Vol. 6, No. 1, Pp. 50-54, 2017.

[9] L. Amaliya, K. Setiaji, S. Pd, M. Pd, And S. Artikel, "Economic Education Analysis Journal Pengaruh Penggunaan Media Sosial Instagram,Teman Sebaya Dan Status Sosial Ekonomi Orangtua Terhadap Perilaku Konsumtif Siswa (Studi Kasus Pada Siswa Kelas Xi Sma Negeri 1 Semarang) Info Artikel Abstrak," Vol. 6, No. 3, Pp. 835-842, 2017, [Online]. Available: Http://Journal.Unnes.Ac.Id/Sju/Index.Php/Eeaj.

[10] H. Sari And L. Anggraeni, "Peran Tipe Gambar, Tagar, Jumlah Likes Dan Informasi Harga Pada Instagram Terhadap Intensi Membeli," J@Ti Undip J. Tek. Ind., 2019, Doi: 
10.14710/Jati.14.2.71-80.

[11] S. Cahyani, R. Wiryasaputra, And R. Gustriansyah, "Identifikasi Huruf Kapital Tulisan Tangan Menggunakan Latent Dirichlet Allocation Dan Euclidean Distance," J. Sist. Inf. Bisnis, Vol. 8, No. 1, P. 57, 2018, Doi: 10.21456/Vol8iss1pp57-67.

[12] F. Fandiansyah, J. Y. Sari, And I. P. Ningrum, "Pengenalan Wajah Menggunakan Metode Latent Dirichlet Allocation Dan K Nearest Neighbor," J. Ultim., Vol. 9, No. 1, Pp. 1-9, 2017, Doi: 10.31937/Ti.V9i1.557. 